\title{
Decomposition analysis of income difference between furrow and border strip method of irrigation in cultivation of wheat in the Malaprabha Command Area of Karnataka
}

\author{
SHREESHAIL RUDRAPUR, B.L. PATIL AND R.A. YELEDHALLI
}

Received : 20.06.2014; Revised : 08.08.2014; Accepted : 22.08.2014

\begin{abstract}
The present study was conducted in the Malaprabha Command Area as many scientific irrigation methods were implemented by the RKVY project. The required data were collected from the 35 farmers each practicing border strip method of irrigation (scientific) and furrow method of irrigation (traditional) in the cultivation of wheat. The data were analysed using the output decomposition model developed by Bisaliah (1977). The study revealed that the adopters of scientific irrigation technology produced 24.87 per cent higher income from border strip method of irrigation than furrow irrigation. The increase in the income was further decomposed into different sources of change such as adoption of scientific irrigation technology and changed input levels. The scientific irrigation technology alone could contribute 23.65 per cent increase in income, while the contribution of change in input levels was found to be positive (1.22 \%). Amongst the various inputs, seed (-0.18\%), fertiliser (-0.53\%) and cost of irrigation $(-2.34 \%)$ contributed negatively where as human labour $(1.41 \%)$, bullock and machine labour $(2.75 \%)$ and FYM (0.11) contributed positively to the income.
\end{abstract}

KEY WORDS : Decomposition analysis, Border strip method of irrigation, Furrow irrigation

How to cite this paper : Rudrapur, Shreeshail, Patil, B.L. and Yeledhalli, R.A. (2014). Decomposition analysis of income difference between furrow and border strip method of irrigation in cultivation of wheat in the Malaprabha Command Area of Karnataka. Internat. J. Com. \& Bus. Manage., 7(2) : 284-288.

\section{MEMBERS OF THE RESEARCH FORUM}

Correspondence to:

SHREESHAIL RUDRAPUR, Department of Agricultural Economics, College of Agriculture, University of Agricultural Sciences, DHARWAD (KARNATAKA) INDIA

Email: shree4476@gmail.com

\section{Authors' affiliations:}

B.L. PATIL, Department of Agricultural Economics, University of Agricultural Sciences, DHARWAD (KARNATAKA) INDIA

R.Y. YELEDHALLI, Department of Agri-Business Management, University of Agricultural Sciences, DHARWAD (KARNATAKA) INDIA 